POLIICALECONOMY RESARCH INSTIUIE

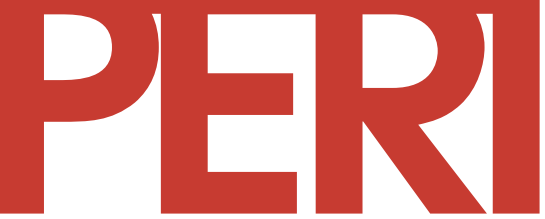

University of Massac husetts Amherst

\title{
Defending the Public Domain: Pollution, Subsidies and Poverty
}

\author{
Paul H. Templet
}

2001

10th floor Thompson Hall

University of Massachusetts

Amherst, MA, 01003-7510

Telephone: (413) 545-6355

Facsimile: (413) 545-2921

Emailsperi@ec onsumassedu Whasite:

htp:// wuw.umassedu/peil/

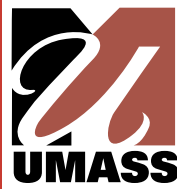




\title{
Defending the Public Domain: \\ Pollution, Subsidies, and Poverty
}

\author{
Paul H. Templet
}

January 2001

Commissioned for the Natural Assets Project

Funded by the Ford Foundation

Program on Development, Peacebuilding, and the Environment

Political Economy Research Institute (PERI) 
University of Massachusetts Amherst 
Freedom has appeared in the world at different times and under various forms; it has not been exclusively bound to any social condition, and it is not confined to democracies. Freedom cannot, therefore, form the distinguishing characteristic of democratic ages. The peculiar and preponderating fact which marks those ages as its own is the equality of conditions; the ruling passion of men in those periods is the love of this equality.

- Alexis de Tocqueville, Democracy in America, 1835

\section{Introduction}

In recent decades, industry has come under criticism for failing to cover the environmental costs of doing businesses. When companies are allowed to pollute, or to use natural resources without paying their full price, they are in effect appropriating natural capital - land, air, and water - without compensation to society at large.

Economists have paid a good deal of attention to the inefficiencies that result when companies pass on, or "externalize," production costs in the form of environmental damage. But few have looked at the broader effects of externalities on public welfare, particularly on the distribution of wealth. The research summarized in this chapter suggests that externalities are an important force behind economic inequality and poverty in the United States. Some degree of inequality is to be expected in any society. But massive disparities are unacceptable in a culture that upholds the principle that all people are created equal - and all the more intolerable when fueled by the seizure of common public assets.

The impetus for the research presented here comes from the four years I spent as Secretary of the Department of Environmental Quality (DEQ) for the state of Louisiana. I was a scientist at Louisiana State University (LSU) in 1987 when Buddy Roemer, a reform-minded candidate, was elected governor. (Roemer was trained at Harvard, but when asked about it he usually replied, "Don't hold that against me.") After his election, Roemer advertised in the Wall Street Journal for positions in his cabinet, an unconventional approach in a state known for political patronage. I had hosted the first Earth Day at LSU in 1970, and had led the development of the state's coastal management program. I had never met the governor, but I liked what I had heard him say about pollution. Having complained for years about environmental destruction in Louisiana, I thought it was time to "put up or shut up." So I applied, along with a couple hundred others, to be environmental secretary. I got the job.

During my tenure, the DEQ expanded its capacity, helped to draft new laws, drew up new regulations, and stepped up enforcement. With nearly every move to tighten up on pollution 
control, we heard from industry and economists on corporate payrolls that we would run jobs out of the state. That assertion didn't make a lot of sense to me, since at the time Louisiana had neither adequate jobs nor a clean environment. The state's unemployment rate was 12 percent in 1987, the highest in the country. The state also led the nation in toxic discharges, according to the first Toxic Release Inventory issued by the U.S. Environmental Protection Agency (EPA) in 1989. It seemed to me that environmental protection would foster jobs rather than diminish them, that a clean environment would be good for people and for the economy. But I needed hard data and analysis to back up this hypothesis.

By the end of my four-year term, amidst much controversy, we had cut the state's toxic discharges in half. We implemented new regulations and passed new laws, including an Air Toxics Law enacted a year before the 1990 Federal Clean Air Act Amendments. At the same time, enforcement went up by a factor of five. We began to condition industrial property tax exemptions on environmental criteria (Templet \& Farber 1994, Farber et al. 1995). Contrary to the warnings from industry, investment and jobs in Louisiana rose as pollution declined (Figure 1). Many jobs were generated by a six-fold increase in

\section{Figure 1: Louisiana Pollution Abatement Capital Outlay and Manufacturing Jobs}

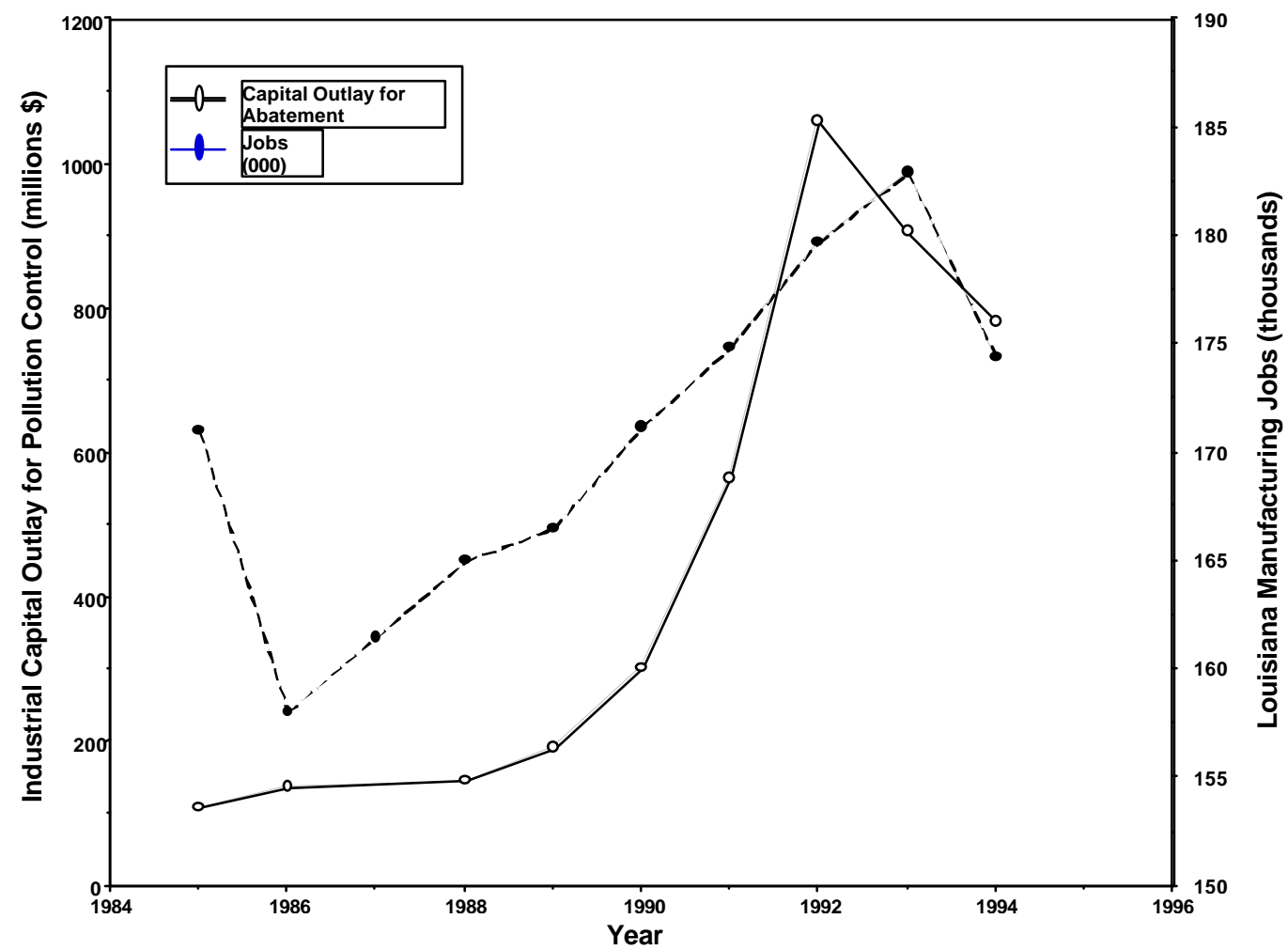

Sources: U.S. Bureau of the Census, State and Metropolitan Area Data Book; US Department of Commerce, Current Industrial Reports, Pollution Abatement Costs and Expenditures; US. Department of Commerce, Economics and Statistics Administration, Annual Survey of Manufactures, Statistics for Industry Groups and Industries 1989. 
spending on industrial pollution control. Other socioeconomic indicators also began to improve (Templet 1995c). When I returned to the university in 1992, I began systematic research on these issues. ${ }^{1}$

\section{Externalities As Subsidies}

All economies depend fundamentally on nature. The environment provides the economy with natural resources needed to produce goods and services, and provides a place for wastes from production and consumption to go (see Figure 2). A diminished environmental base threatens economic welfare. If, for example, industry discharges more waste than the environment can assimilate, toxins accumulate in fish and wildlife, and threaten commercial and sport fishing. Acid rain and air pollution damage crops and trees, retarding agriculture and forestry. On the other hand, cities and regions that maintain clean air and aesthetic appeal are more likely to attract business and tourism. If ground and surface water are kept relatively clean, then minimal treatment is needed for human consumption, so the public spends less. And conservation leaves more resources available for future generations.

\section{Figure 2: The Relationship of the Economy to the Environment}

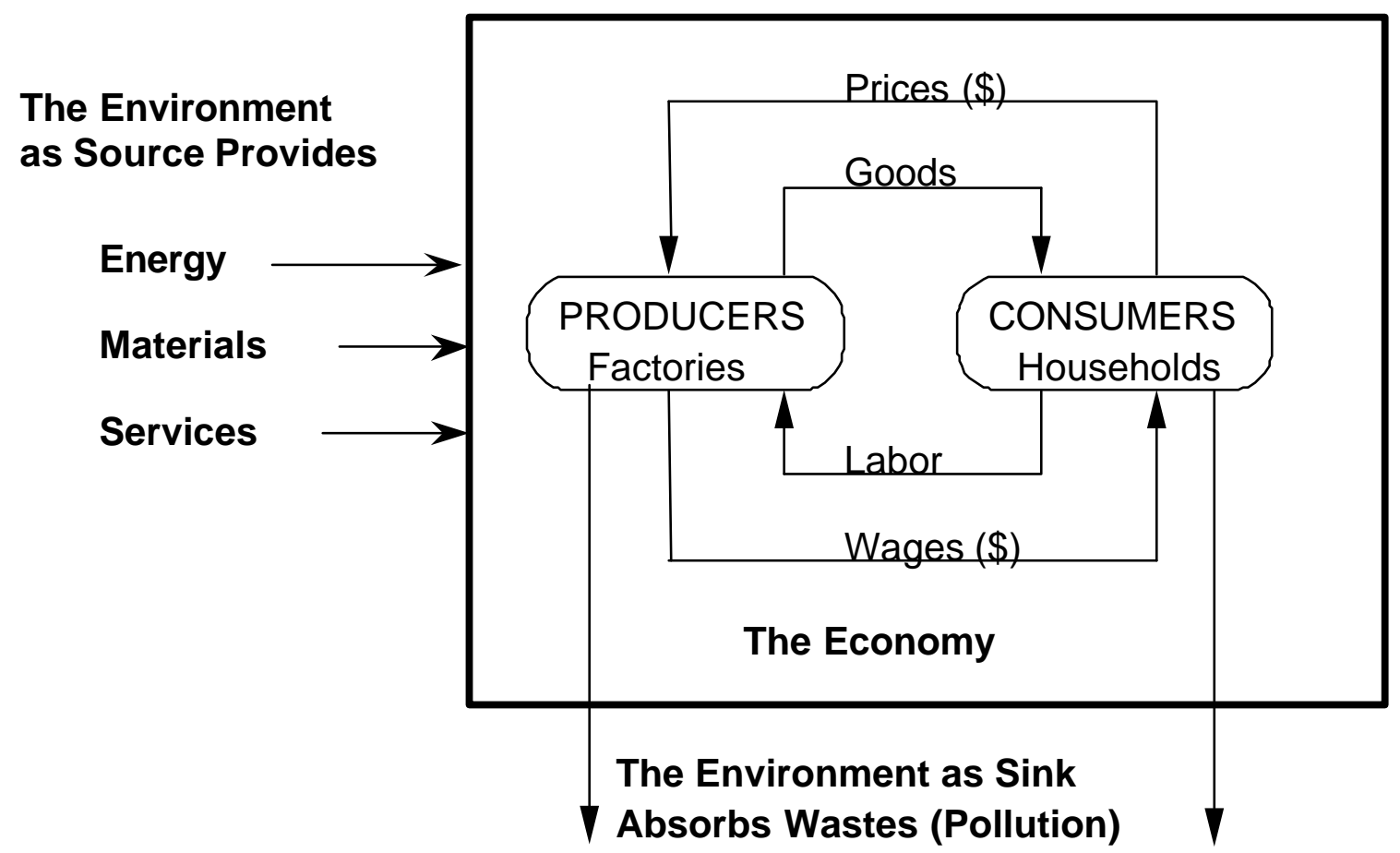

The environment can be viewed as infrastructure, contributing to the economy in a similar fashion as man-made systems for water delivery and waste disposal. Just as the public welfare suffers when our built infrastructure is poorly maintained, so we suffer when the environment is abused. Those who pollute without paying the costs are depreciating capital that belongs to society at large. 
But while society normally penalizes those who steal or embezzle public financial capital, we persist in allowing the unauthorized appropriation of public natural capital, despite the fact that natural capital is arguably more valuable to humankind than the entire stock of man-made capital (Costanza et al. 1997).

When producers externalize costs, they reap a subsidy. A firm releasing toxins to the environment, for example, is spared the expense of controlling that pollution, instead appropriating natural capital from the sink side. The result of this implicit subsidy is greater corporate profit, while those on the receiving end are burdened with pollution, health problems, and diminished quality of life. The result is a redistribution of wealth that tends to exacerbate socio-economic inequalities.

Producers also receive subsidies in the form of preferential energy prices and favorable tax rates. In these instances, the public pays the cost directly. One way in which vested interests manage to create subsidies for themselves is through political clout. The more that members of Congress receive in campaign contributions, for example, the more they tend to vote in favor of industry and against environmental protection; the poorer a Congress person's voting record on the environment, the more subsidies his or her state tends to grant to industry (Templet 1995a).

Subsidies foster inequality in three ways. First, they diminish productivity, disposable incomes, health, and quality of life of those who bear their cost. Second, subsidies help the recipients to bolster their political power, which they can use to manipulate both government policies and markets to their advantage. Third, subsidies deprive the government of revenues which it might otherwise use for education, health care, and other programs that serve citizens. In the research presented here I examine only the first two effects, leaving aside fiscal impacts. I do so by exploring the correlations between subsidy measures and environmental and socioeconomic indicators in the 50 states. The aim is to document how externalities contribute to inequality and poverty, and to consider how the public can re-appropriate natural capital.

\section{Measuring Subsidies}

Absolute subsidies are difficult to measure, since they can be calculated only by comparison to a hypothetical, subsidy-free world. Instead of attempting this, I calculate each of the three subsidies discussed below relative to the U.S. average. Those states paying below average subsidies are still paying subsidies, but their value is negative relative to the mean. If states with lower subsidies can be shown to have higher public welfare, then one can infer that a reduction in subsidies would benefit welfare in all states, and that those states with the biggest subsidies have the most to gain.

\section{The pollution subsidy}

State laws and regulations generally require that industry internalize pollution costs to some degree (Templet 1993). While there are also federal laws to regulate emissions, states have 
considerable latitude in administering them. For both reasons, spending on pollution control varies considerably from one state to another. ${ }^{2}$

For the purposes of this study, I define the pollution subsidy as the degree to which a state falls short of the nationwide average on spending to control pollution. Of course, states with more industries using toxic chemicals should spend more on pollution control. The pollution subsidy is therefore specified as the costs that manufacturers avoid by spending less than the national average per pound of toxic pollution times total pounds released in a state.

I use data on spending on pollution control from the Current Industrial Reports of the U.S. Census Bureau (1992). Regrettably, the Census Bureau no longer collects this information, because after the Republican Party gained a majority in Congress in 1994, lawmakers cut the Bureau's budget and eliminated this function. The data on pounds of toxic releases are drawn from the U.S. Environmental Protection Agency's (1991) Toxics Release Inventory. For interstate comparisons, I then calculate the pollution subsidy, based on these data, in dollars per capita. The results are presented in Table 1.

Table 1: Relative Subsidies in the Fifty States (\$ per capita)

\begin{tabular}{|c|c|c|c|c|}
\hline State & Pollution subsidy & Energy subsidy & Tax subsidy & Total subsidy \\
\hline Alabama & 59 & 103 & 196 & 357 \\
\hline Alaska & 192 & 218 & -396 & 13 \\
\hline Arizona & 98 & 57 & 155 & 310 \\
\hline Arkansas & 48 & 43 & 129 & 220 \\
\hline California & -48 & -100 & -51 & -200 \\
\hline Colorado & -51 & -104 & 2 & -153 \\
\hline Connecticut & -38 & -315 & 39 & -313 \\
\hline Delaware & -243 & 6 & -242 & -479 \\
\hline Florida & 17 & 175 & 232 & 424 \\
\hline Georgia & -26 & -11 & 38 & 1 \\
\hline Hawaii & -22 & 10 & 257 & 244 \\
\hline Idaho & 2 & -27 & 21 & -5 \\
\hline Illinois & -22 & -180 & 35 & -167 \\
\hline Indiana & 32 & 40 & 29 & 101 \\
\hline Iowa & 30 & -43 & -105 & -117 \\
\hline Kansas & 172 & -90 & -14 & 68 \\
\hline Kentucky & -42 & -171 & 45 & -169 \\
\hline Louisiana & 410 & 183 & 286 & 879 \\
\hline Maine & -103 & -119 & -26 & -248 \\
\hline Maryland & -47 & -41 & -142 & -230 \\
\hline Massachusetts & -12 & -427 & -301 & -740 \\
\hline Michigan & -11 & -335 & -207 & -553 \\
\hline Minnesota & 10 & -231 & -114 & -336 \\
\hline Mississippi & 170 & 85 & 156 & 410 \\
\hline Missouri & 11 & -85 & 113 & 39 \\
\hline Montana & 283 & -121 & -260 & -98 \\
\hline Nebraska & 46 & -95 & -63 & -112 \\
\hline
\end{tabular}




\begin{tabular}{|l|c|c|c|c|}
\hline State & Pollution subsidy & Energy subsidy & Tax subsidy & Total subsidy \\
\hline Nevada & 7 & -111 & 450 & 346 \\
\hline New Hampshire & -7 & -515 & -240 & -762 \\
\hline New Jersey & -77 & -222 & -126 & -426 \\
\hline New Mexico & 65 & -75 & 283 & 274 \\
\hline New York & -27 & -121 & -253 & -401 \\
\hline North Carolina & 28 & 12 & -3 & 36 \\
\hline North Dakota & 7 & 53 & 58 & 118 \\
\hline Ohio & -17 & -102 & -31 & -149 \\
\hline Oklahoma & 29 & 107 & 126 & 262 \\
\hline Oregon & -16 & -57 & -404 & -477 \\
\hline Pennsylvania & -38 & -44 & -40 & -122 \\
\hline Rhode Island & -43 & -201 & -98 & -342 \\
\hline South Carolina & -5 & 83 & 63 & 140 \\
\hline South Dakota & 13 & -66 & 127 & 73 \\
\hline Tennessee & 174 & -59 & 309 & 424 \\
\hline Texas & 14 & 159 & 142 & 315 \\
\hline Utah & 411 & -11 & 42 & 441 \\
\hline Vermont & -16 & -326 & -123 & -465 \\
\hline Virginia & 30 & 80 & -41 & 69 \\
\hline Washington & -39 & -49 & 442 & 354 \\
\hline West Virginia & 3 & 67 & 172 & 243 \\
\hline Wisconsin & -44 & -155 & -140 & -339 \\
\hline Wyoming & 102 & -107 & -115 & -120 \\
\hline Note: Figures for subsidies represent spending relative to the nationwide average (see text). & \\
\hline
\end{tabular}

\section{The energy subsidy}

To varying degrees in different states, residents pay more for energy than industry. In effect, consumers subsidize industry. If the price differential is great, residents may not be able to afford enough fuel themselves, or they may have to forego other wants.

To measure the energy subsidy to industry, I collected data on energy expenditures by the industrial sector in each state, from the US Energy Information Agency, and on the ratio of residential to industrial prices. On average across the United States, residents pay approximately twice what industry pays for an equal amount of energy. Some level of disparity can be justified on the basis that firms consume in larger volumes, and thus the cost of delivering energy to a firm is cheaper than delivering the same amount to multiple households. But price differentials vary widely, with the ratio of residential to industrial prices ranging from 1.01 in New Hampshire and Massachusetts to 4.0 in Alaska. The energy subsidy is defined here as how much more the industrial sector in each state would spend if the residential-to-industrial price ratio were equal to the U.S. average. Again, the subsidy is normalized by the state's population. ${ }^{3}$ The results are presented in the second column of Table 1.

\section{The tax subsidy}


Most states rely on a mix of sales, income, and property taxes to generate public revenues. Some of these methods are more progressive than others in their distributional impacts. In general, income and property taxes tend to be progressive; that is, they take a larger share of income from the rich than from the poor. Sales taxes, by contrast, take a fixed share of the amount consumed. Since those with low and modest incomes generally spend a higher share of their income on consumption than do the rich, sales taxes tend to be regressive.

To obtain a measure of the tax subsidy to business, I calculated for each state the ratio of regressive taxes collected to progressive taxes collected - considering property and income taxes to be progressive, and sales taxes to be regressive - and compared that ratio to the U.S. average. A state that relies more heavily than average on regressive taxes is considered to provide a subsidy to those with high incomes and large property holdings, a subsidy paid for by those with low incomes and little property. I then divide the total dollar value of this subsidy by state population. ${ }^{4}$ (These results are reported in the third column of Table 1.)

\section{The total subsidy}

The total state subsidy per capita is the sum of the pollution, energy, and tax subsidies per capita. The totals are presented in the final column of Table 1 and depicted in Figure 3. In general, the states with relatively high subsidies tend to be in the South and to a lesser extent the West. The Northeast and Midwest tend to grant fewer subsidies.

In addition to pollution, energy and tax subsidies, many southern states also are liberal in granting direct subsidies expressly designed to attract industry. The South and West have been later to industrialize than other regions, and this may help to explain their greater tendency to allow industry to externalize costs more, much as developing countries often do (Templet 1996). Yet Freudenberg (1990) finds that "there is evidence that the communities gaining the most from industrial development are the ones that have spent the least to attract it."

\section{The Fruits of Subsidies}

Having calculated these subsidies, I examined their relationships to various measures of environmental and economic performance. To relate these to subsidies, I estimated statistical correlation coefficients of variation across the 50 states by means of simple linear regressions. This section highlights the key results.

\section{Subsidies and environmental performance}

To examine the relationships between subsidies and environmental performance, I used the state-level measures of environmental policy and environmental quality, developed by the Institute for Southern Studies (Hall and Kerr 1991). The Green Policy index incorporates 77 indicators, such as the existence of state policies on recycling, toxic waste management, and air 
pollution, and ratings of state environmental programs. The Green 
Conditions index is based on 179 other indicators, including measures of air and water pollution and toxic chemical releases. In both cases, the higher the score, the poorer the state's environmental status.

Not surprisingly, the correlation between the pollution subsidy and the Green Policy Index was significant and positive $(\mathrm{r}=0.52)$ : the higher the pollution subsidy, the lower the state ranked in the strictness of its environmental standards and enforcement. The energy subsidy is also significantly and positively related to the Green Conditions index $(r=0.47)$ and Green Policy index $(\mathrm{r}=0.52)$, indicating that as the energy subsidy increases, environmental protection grows weaker. The tax subsidy, too, is associated with worse environmental performance; its correlation with the Green Index (a combination of the quality and policy indices) is significant and positive $(\mathrm{r}=0.44)$.

\section{Subsidies and economic performance}

The pollution subsidy is correlated with worse economic performance in terms of poverty, income disparity, unemployment, and average personal income. These findings run counter to the claim that the benefits and costs of pollution control are regressive, with the costs falling disproportionately on the poor while benefits accrue elsewhere (Baumol and Oates 1988). Instead, as firms externalize more costs, poverty and income disparity increase, and incomes decline. This suggests that spending to control pollution constitutes a progressive policy in terms of income distribution. The benefits may be more than just economic, since it is the poor, and often minorities, who are most likely to live near polluting facilities. ${ }^{5}$

The energy subsidy displays similar correlations: it is significantly and positively related to poverty $(\mathrm{r}=0.46)$, unemployment $(\mathrm{r}=0.51)$, and income disparity $(\mathrm{r}=0.49)$, and negatively related to personal income $(\mathrm{r}=-0.45)$. The tax subsidy, too, is related significantly and negatively to personal income ( $\mathrm{r}=-0.39)$, and positively to income disparity $(\mathrm{r}=0.31)$ and poverty $(\mathrm{r}=0.42)$. Because the tax subsidy is regressive, drawing from the poor and middle class and benefiting the wealthy, it is no surprise that higher tax subsidies lead to more poverty and to wider income disparity.

I also examined the relationship between the pollution subsidy and job growth in the late 1980s, and found the correlation to be significant and negative ( $r=-0.41)$, indicating that as firms avoid the costs of pollution control, the state foregoes jobs. This finding is consistent with Louisiana's experience in 1988 to 1992 under the Roemer administration, when manufacturers increased spending on pollution control by 600 percent, toxic releases dropped by more than 50 percent, and manufacturing jobs in the state grew by 20,000. As Figure 1 shows, manufacturing jobs in Louisiana had been declining prior to 1988, and after 1992, when pollution spending began to decline again under a new administration, manufacturing jobs fell once again. ${ }^{6}$

In the realm of profits, on the other hand, one would expect that subsidies would have a positive effect. Data on corporate profits are not available by state, but we can use a surrogate measure 
- value added in manufacturing - to test whether profits increase when the pollution subsidy rises. ${ }^{7}$ Value added is normalized by the number of manufacturing jobs to adjust for sector size across states. I found that value added per job is indeed significantly and positively related to the pollution subsidy, suggesting that corporate profits rise when pollution control costs are avoided. Louisiana, for example, leads the nation in value added per manufacturing job, at nearly double the national average. It also leads the nation in toxic pollution per job, at more than ten times the natural average. ${ }^{8}$ The energy subsidy likewise shows a significantly positive relationship with value added per job in manufacturing.

If firms were to invest these added profits within the state, then they might contribute to public welfare through increased employment and income. In that case, some of their de facto appropriation of natural capital might be justified. In fact, however, most of the profits go to shareholders and managers, who often reside in other states. In general, profits tend to leak from high-subsidy, low-income states to low-subsidy, high-income states, fueling inter-state inequality. I return to this issue below.

\section{Making Connections}

As pollution, energy, and tax subsidies rise, poverty and income disparity increase. Profits rise but leak out of the state, reducing income. Unemployment rises, also reducing income. Natural capital is depleted and toxic emissions rise. The connections extend further. Poorer environmental quality is associated with worse public health (Boyce et al. 1999); and increased morbidity, mortality, and health care costs represent a further drag on the economy. At the same time, disparities of income within and between states foster the concentration of political power in fewer hands. A vicious cycle ensures, whereby more concentrated power leads to more subsidies, which again lead to more poverty, inequity, and concentrated power. Figure 4 depicts some of these rather complex inter-connections.

Figure 4: Subsidies, Poverty and the Government

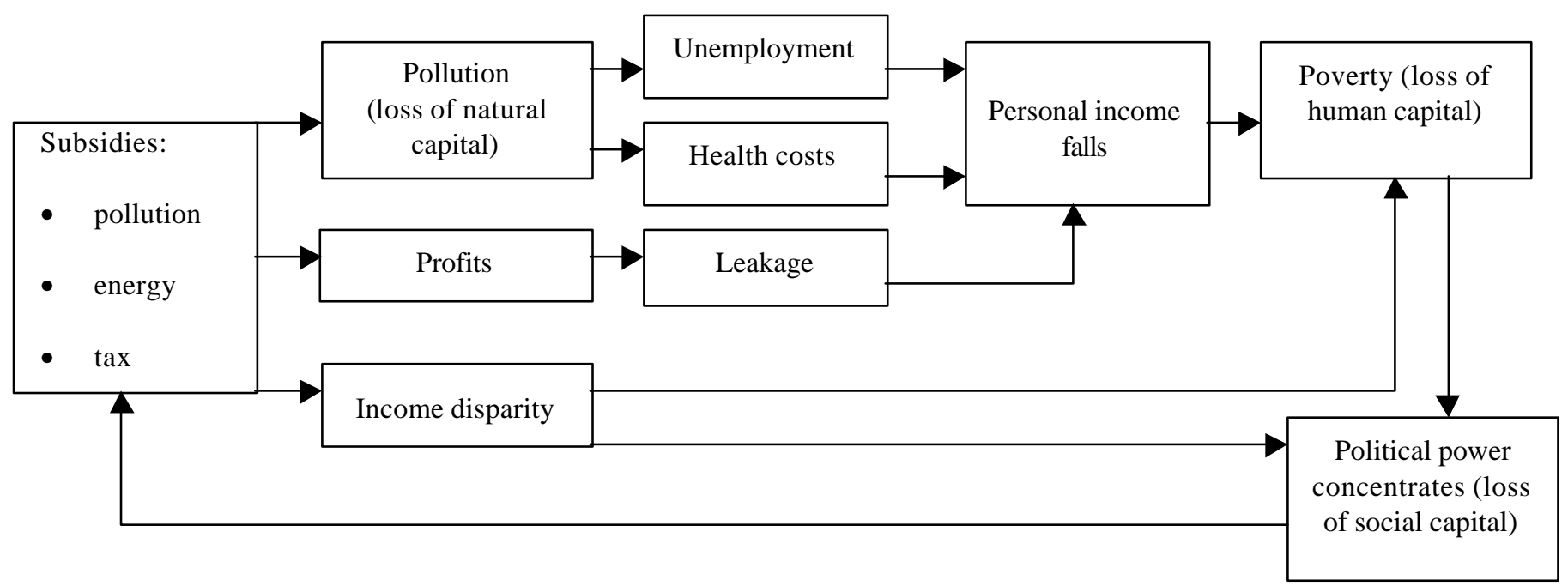




\section{Subsidies and political power}

A troubling correlate of high subsidies is low voting rates. An active voting public is critical to a democratic society, and is one indicator of the extent of social capital. Among states with above-average total subsidies, participation in federal elections is on average 15 percent lower than the U.S. average. Citizens in high-subsidy states may well feel disenfranchised, perceiving that their elected representatives cater to special interests. They may doubt that voting will change anything. Yet low participation itself contributes to the further concentration of power.

Those receiving subsidies can use additional financial capital in a number of ways. One obvious way is to spend more on campaign contributions, and to hire more lobbyists to protect and augment the subsidies. Industrial corporations are major contributors to political campaigns. In making contributions, special interests not only help to elect representatives who serve their interests, but may also influence choices for appointed positions.

In my experience as a cabinet official in Louisiana's state government, I found that the quality of public leadership declines as special interests increase their sway. Even federally funded programs tend to languish. State agencies become less responsive to citizens, who in turn withdraw from the political process. The state becomes a less attractive place to live and do business. The end result is institutional failure, the erosion of democracy and the loss of social capital.

Again and again, decision makers hear the refrain that higher environmental standards will drive away firms and jobs and lower welfare. Yet much empirical research supports my own findings to the contrary. For example, Meyer (1992) found that worker productivity, employment, and growth rates are lower in states with poorer environmental rankings. Cannon (1993) likewise found that economic growth rates were lower in states with poorer environmental records. The fact that environmental protection and economic welfare go hand in hand must be impressed upon public officials.

\section{Leakage}

Large companies are the biggest beneficiaries of subsidies; they use the most energy and other resources, discharge the most waste, and have the largest incomes and property holdings. If all of the profits generated by subsidies were to remain in the state, the recycling of the extra income might counter at least some of the harm that subsidies inflict on public welfare. Many of the profits are exported, however, to shareholders and managers living in other states. In fact, value added per job - the surrogate measure for profits - is positively and significantly related to the share of gross state product that leaves the state. The greater the subsidies, the greater the profits, and the greater the rate of leakage.

Louisiana again offers a case in point. It has the highest subsidies in the country, as well as the highest value added per manufacturing job. Yet only two-thirds of the annual gross state 
product accrues as income within the state (U.S. Bureau of the Census 1997). The remainder, roughly $\$ 5,000$ per person annually, is exported to other states, or even to other countries since some of the firms are foreign-owned. If Louisiana were instead to retain this profit, the state's per-capita income would be close to the U.S. average.

Leakage is a major source of income disparities among states. It drains income from states that use the most resources and generate the most pollution, relying heavily on such industries as mining, manufacturing, and logging. These states tend to be poorer than average. The profits leak to richer states, which tend to pay smaller subsidies and to export less income. As leakage declines, income rises; as income declines, leakage rises. A number of the richer states import net income; that is, their total income exceeds their state product.

As income leaks from a state, we see rises in unemployment, poverty, and pollution. The situation is analogous to colonialism, in which the mother country draws resources and other wealth from the colony, proffering little compensation in return. In this respect, the United States displays a kind of internal colonialism.

\section{Policy Recommendations}

Society can improve both public welfare and environmental quality by cutting subsidies and by taking back the commons, so as to restore natural capital to citizens. Campaign finance reform is critical to electing officials who will work for change, in the face of opposition from the entrenched interests who will try to defend the status quo.

\section{Cutting subsidies}

The pollution subsidy is a sink subsidy: it is based on cost-free access to the pollution-absorbing capacity of the environment. We need laws, regulations and enforcement to minimize industrial discharges, and to re-appropriate this national asset. Economic incentives can be useful, in particular to reach goals beyond minimal thresholds, but they are not sufficient by themselves. State inspections of facilities, for example, have been found to have more impact on environmental performance than incentives (Dasgupta et al. 1999).

One way to give firms a greater incentive to reduce pollution is to award tax exemptions based on environmental performance. In Louisiana, we devised an Environmental Scorecard to rate firms, and conditioned a firm's property tax exemption on its annual score. ${ }^{9}$ The rating was based on level of toxic discharges per job, and on compliance with environmental regulations, i.e. how many penalties a firm had incurred over a designated time period. Firms could also apply for bonus points, for example, by submitting a waste reduction plan or locating in areas needing development. Depending on its score, a firm could receive 50 to 100 percent of the requested exemption. Each percentage point could mean hundreds of thousand of dollars, so the incentive to perform well was substantial. Unfortunately, industry opposed the incentive 
vociferously, and after Buddy Roemer was defeated for a second term, the new governor's first official act was to eliminate the Scorecard.

The energy subsidy is a source subsidy: it reduces the cost of obtaining a natural resource. There is no particular reason that industry should enjoy drastically cheaper energy than the public does. Some discount for volume may be justified, but economies of scale do not explain why residents pay four times as much as industry in Louisiana and Alaska, while the average U.S. resident pays only twice the industrial price. The huge price differences in certain states reflect political power. Eliminating the energy subsidy would return the appropriated natural assets to citizens in the form of reduced pollution and more equitable prices. It would also promote more efficient use of energy, and enhance public health. Citizens could spend less on energy, and more on education or other needs.

One way to gauge a "fair" price for energy is to use the nationwide average ratio of residential to industrial prices as a standard. Cutting above-average subsidies would not internalize all costs, but it would be a step in that direction. Energy prices that reflected all costs, including the associated security and environmental costs, would be much higher than current U.S. prices, and nearer to those of Europe. Higher prices for industrial energy would encourage greater efficiency in U.S. industry, which is currently among the least energy-efficient of industrialized countries. Nationally, empirical data show a significant and positive relationship ( $\mathrm{r}=0.67)$ between industrial energy prices and economic growth (Templet 1999).

In the area of taxation, a shift from regressive sales taxes to taxes on resource use and waste releases would create stronger incentives to conserve resources and to reduce pollution. ${ }^{10}$ Environmental taxes would require payment for the privilege of using natural capital as source or sink. Citizens who use less would benefit from lower taxes, less pollution, and conservation. Pollution-related health spending would also decline.

The distribution of income, property and sales taxes could also be adjusted to establish a reasonable ratio of regressive to progressive taxes. Again, the U.S. average ratio might serve as a standard. States with above-average tax subsidies could reduce their sales taxes and correspondingly raise income and/or property taxes, in addition to raising revenues from source and sink taxes.

\section{Campaign finance reform}

All of these reforms will be difficult to enact. Entrenched interests that benefit from current subsidies will use their political power to fight change. Hence the need for campaign finance reform. The correlation among the size of campaign contributions, Congressional environmental voting records and state subsidies to industry do not establish a conclusive case, but they suggest that campaign contributions help to promote subsidies for vested interests. Campaign finance reform is essential to curb the purchase of influence through campaign contributions, and to make room for progressive environmental policies. 


\section{Conclusion}

When firms externalize environmental costs, they appropriate de facto property rights to natural capital. They capture subsidies, and the public pays the price. These firms often use political clout to advance their interests. The resulting state policies tend to make the state less attractive to other firms, reducing the diversity of businesses (Templet 1996). Communities may be left with a "company town" syndrome. They grow poorer, more polluted, more subject to boomand-bust cycles, and more dependent on the industries that are reaping the benefits. As concentrated wealth fosters concentrated power, public policy embraces subsidies even more. The result is a spiral of public and ultimately private decline. Although corporations can eventually pick up and go elsewhere, the public as a whole cannot.

This negative scenario can be averted by requiring businesses to internalize their costs. We can reduce or eliminate pollution, energy, and tax subsidies in favor of a more equitable system. We can shift to progressive taxes and to taxes on the things we want to avoid - excessive resource use and pollution. A tax on resource use will promote conservation and improvements in efficiency. A tax on waste releases will encourage firms to pollute less, improving efficiency, health, and quality of life. By reallocating natural capital to the public domain, we can both protect the environment, reduce poverty, and improve quality. As Alexis de Tocqueville pointed out 166 years ago, equality is a defining characteristic of American democratic society. Environmental abuse is bad not only for our health, but also for our democratic ideals. 


\section{Endnotes}

${ }^{1}$ In 1991, Buddy Roemer lost his bid for a second term as governor, in the face of much softmoney spending by industry to defeat him. Some of our reforms were rolled back by the next two governors, but others remained in place.

2 The effectiveness of state policy depends not only on laws and regulations but also on enforcement. In Louisiana, for example, the state imposed only 25 percent as many penalties in 1997 as it did per year when Governor Roemer was in office from 1988 to 1992. The size of the penalties also dropped, with the dollar amount of fines in 1997 less than 10 percent of the 1989 level. Not surprisingly, pollution in Louisiana is increasing again: lax enforcement means greater subsidies.

${ }^{3}$ For details regarding these calculations, see Templet (1995b).

${ }^{4}$ For details, see Templet (1995b). As would be expected, the tax subsidy per capita is significantly and negatively correlated with the "tax fairness" score constructed by the Corporation for Enterprise Development (1995), a non-profit research and policy organization which monitors economic development in the 50 states.

${ }^{5}$ See Chavis and Lee (1987), Bullard (1990), Pastor (2001), and Bouwes et al. (2001).

${ }^{6}$ The contribution of pollution-control spending to jobs is even more impressive when directly compared to other state schemes to promote employment. A study by Management Information Services (American Chemical Society 1993) found that every additional million dollars spent on pollution control creates 22 jobs in the pollution control sector alone (not counting any multiplier effects on employment in other sectors). By contrast, Louisiana has had little success with tax incentives aimed expressly to create jobs: Louisiana has lost about 15,000 manufacturing jobs since 1980, while paying out over $\$ 5$ billion in tax subsidies.

${ }^{7}$ Value added is the value of shipments minus the cost of raw materials. Subtracting other production costs from value added would yield profits.

${ }^{8}$ In 1990, Louisiana's Toxics Release Inventory emissions per job in the emitting sector amounted to 2,496 pounds, compared to a US average of 188 pounds (Templet 1995a).

${ }^{9}$ For details, see Templet et al. (1991), Templet and Farber (1994), and Farber et al. (1995).

${ }^{10}$ For reviews of tax shifting experience in other countries, see Roodman (1999) and Ekins (1999). 


\section{References}

American Chemical Society. 1993. "Currents," Environmental Science \& Technology 27(5): 771.

Baumol, W.J. and W.E. Oates.1988. The Theory of Environmental Policy. 2nd. ed. Cambridge, MA: Cambridge University Press.

Bouwes, N.W., S.M. Hassur, and M.D. Shapiro. 2001. "Empowerment Through Risk-Related Information: EPA's Risk-Screening Environmental Indicators Project." In Natural Assets: Democratizing Community Ownership, edited by J. K. Boyce and B. G. Shelley. New York: Russell Sage Foundation Press.

Boyce, J.K., A.R. Klemer, P.H. Templet., and C.E. Willis. 1999. "Power Distribution, The Environment, and Public Health: A State Level Analysis." Ecological Economics 29: 127-40.

Bullard, R.D. 1990. Dumping in Dixie: Race, Class and Environmental Quality. Boulder, CO.: Westview Press.

Cannon, F. 1993. "Economic Growth and the Environment." In Economic and Business Outlook. San Francisco: Bank of America, Economics-Policy Research Department. (415) 622-3215.

Chavis, B.F. and C. Lee. 1987. Toxic Wastes and Race in the United States. New York: Commission for Racial Justice, United Church of Christ.

Corporation for Enterprise Development. 1995. The 1995 Development Report Card for the States. Washington, D.C.

Costanza, R., R. D’Arge, R. de Groot, S. Farber, M. Grasso, B. Hannon, S. Naeem, K. Limburg, J. Paruelo, R.V. O’Neill, R. Raskin, P. Sutton, and M. van den Belt. 1997. "The Value of the World's Ecosystem Services and Natural Capital." Nature 387; 253-60.

Dasgupta, S., B. Laplante, N. Mamingi, and H. Wang. 1999. "Inspections, Pollution Prices and Environmental Performance: Evidence from China." Ecological Economics [Forthcoming].

Ekins, P. 1999. "European Environmental Taxes and Charges: Recent Experience, Issues and Trends." Ecological Economics 31: 39-62.

Farber, S., R. Moreau, and P.H. Templet. 1995. “A Tax Incentive Tool For Environmental Management: An Environmental Scorecard.” Ecological Economics 12: 183-189.

Hall, B. and M.L. Kerr. 1991. Green Index. Institute for Southern Studies. Durham, N.C.: 
Island Press.

Meyer, S.M. 1992. "Environmentalism and Economic Prosperity: Testing the Environmental Impact Hypothesis." Working Paper Series No.1. Cambridge, Mass: Project on Environmental Politics and Policy, Massachusetts Institute of Technology.

Pastor, M. 2001. "Building Social Capital to Protect Natural Capital: The Quest for Environmental Justice." In Natural Assets: Democratizing Community Ownership, edited by J. K. Boyce and B. G. Shelley. New York: Russell Sage Foundation Press.

Roodman, D.M. 1999. "Building a Sustainable Society." In State of the World 1999. Worldwatch Institute. New York: W.W. Norton and Co.

Templet, P.H. 1993. "The Emissions-to-Jobs Ratio; A Tool for Evaluating Pollution Control Programs." Environmental Science and Technology. 27(5): 810-12.

----. 1995a. "Grazing the Commons: Externalities, Subsidies and Economic Development." Ecological Economics. 12: 141-159.

----. 1995b. "Equity and Sustainability; An Empirical Analysis." Society and Natural Resources 8: 509-523.

----. 1995c. "The Positive Relationship Between Jobs, Environment and the Economy: An Empirical Analysis." Spectrum. Spring: 37-49.

---- 1996. "The Energy Transition in International Economic Systems: An Empirical Analysis of Change During Development." International Journal of Sustainable Development and World Ecology 3: 1-18.

----. 1999. "Diversity and Development in Economic Systems; An International Empirical Systems Analysis.” Ecological Economics 30: 223-233.

Templet, P.H. and S. Farber. 1994. "The Complementarity Between Environmental and Economic Risk: An Empirical Analysis." Ecological Economics 9: 153-65.

Templet, P.H., J. Glenn, and S. Farber. 1991. "Louisiana Ties Environmental Performance to Tax Rates." Environmental Finance. Autumn.

de Tocqueville, A. 1835 [1961 translation]. Democracy in America. Translated by Henry Reeve. New York: Schocken Books. Vol. II, Book 4, pp. 343-355, 378-386.

U.S. Bureau of the Census. 1992. Current Industrial Reports, Pollution Abatement Costs and Expenditures MA200(90)-1, Washington, D.C. 
----. 1997. Statistical Abstract of the US: 1997 (117th ed.). Washington, D.C.

U.S. Environmental Protection Agency. 1991. Toxics in the Community, National and Local Perspectives, The 1989 Toxics-Release Inventory National Report. EPA 560/4-91-014. Washington, D.C.: U.S. Government Printing Office. 


\section{The Author}

Dr. Paul Templet is a professor of environmental studies at Louisiana State University. He has been involved in environmental issues in Louisiana since 1969. He teaches environmental planning and management and conducts research concerning environmental management, risk assessment, energy analysis, and systems analysis of economic and environmental systems. He was Secretary of the Louisiana Department of Environmental Quality from 1988-1992 and has developed and implemented Coastal Management Programs in Louisiana and American Samoa. His current research involves the connections between economy and environment.

\section{The Natural Assets Project}

The Natural Assets Project, based at the Political Economy Research Institute of the University of Massachusetts, Amherst, is a collaborative initiative launched with support from the Ford Foundation. The project aims to promote critical analysis and discussion of the potential for building natural assets - individual and social wealth based on natural resources and ecosystem services - to advance the goals of poverty reduction, environmental protection, and environmental justice. 
Figure 3: Total Subsidy by State Relative to the National Average

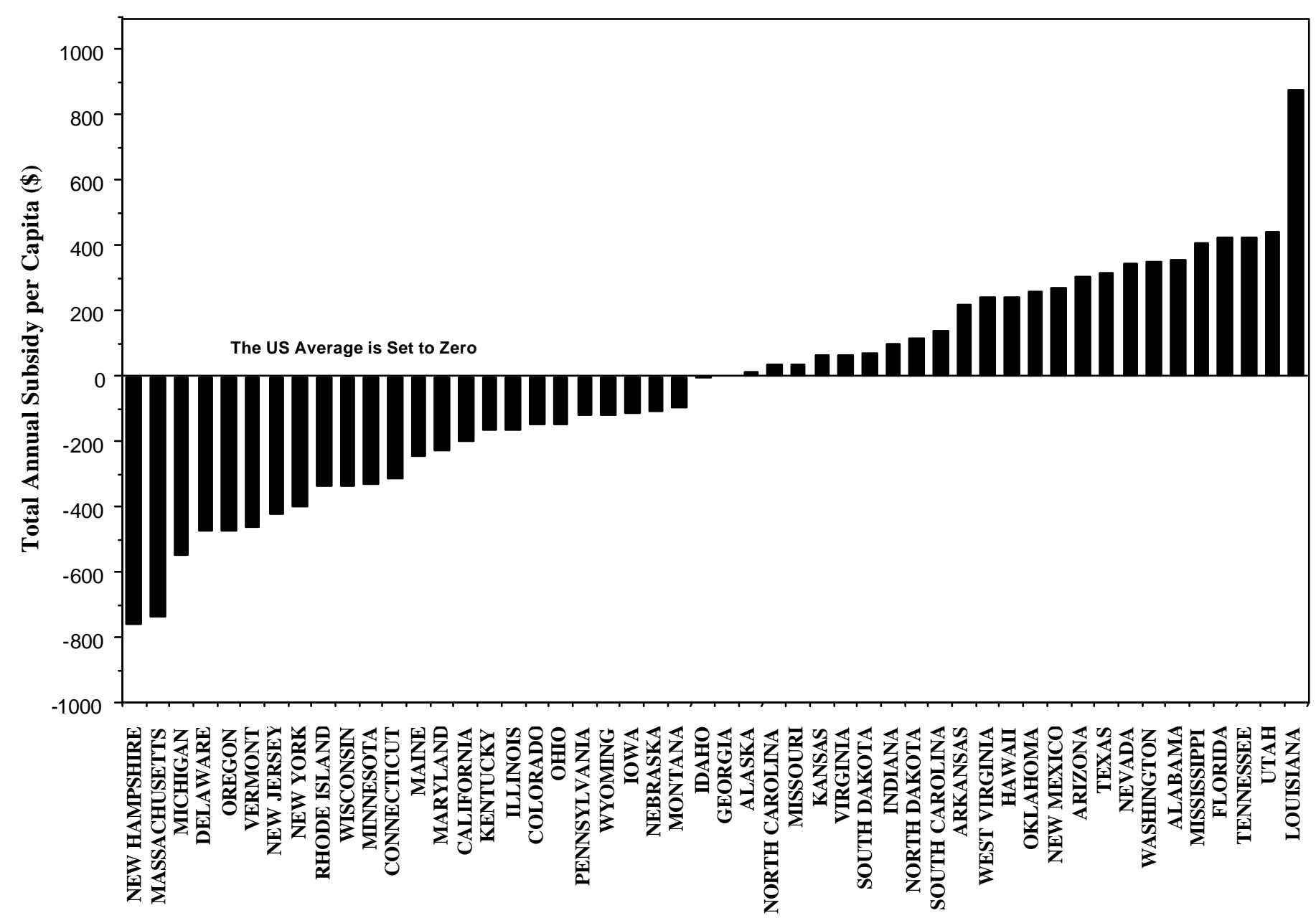


Figure 4: Subsidies, Poverty and the Government

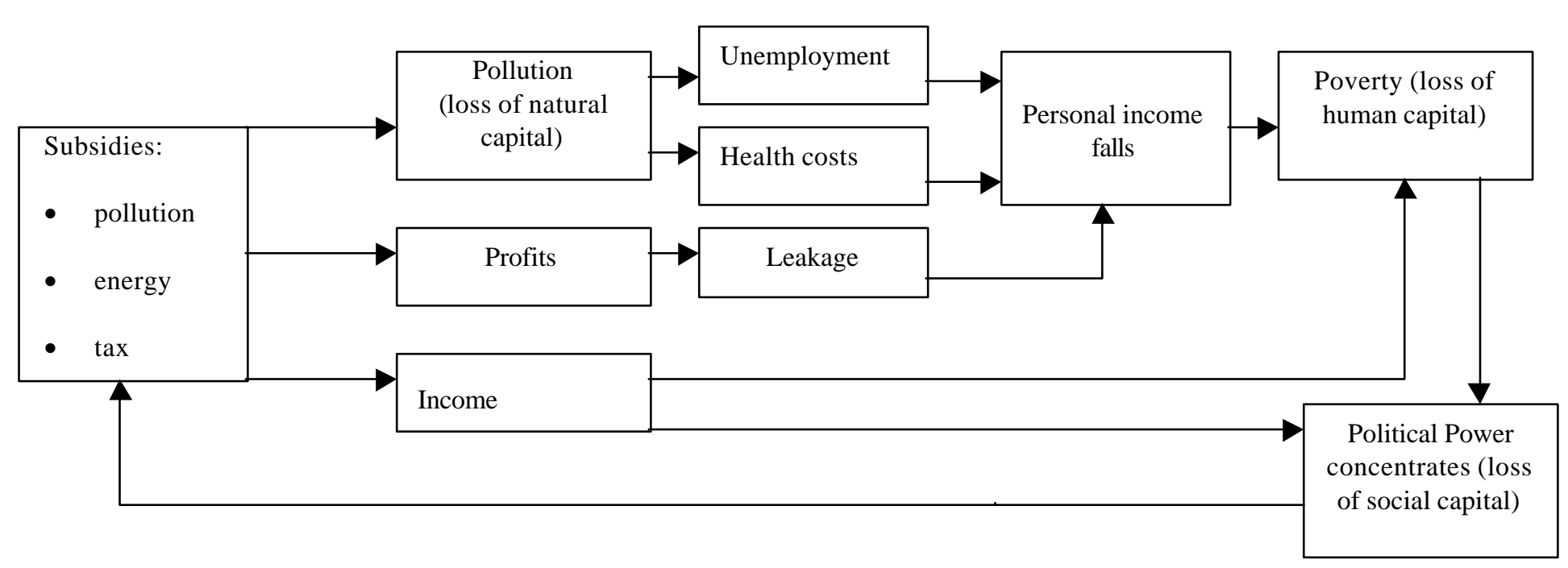

